\title{
Ann Winblad, Entrepreneur and Venture Capitalist
}

\section{David Deeds (University of St. Thomas)}

KEYWORDS: Entrepreneurship, Venture Capital, Strategy, Alliance Management, Women, Learn From Leaders.

In a candid interview with EIX's David Deeds, Ann Winblad, co-founder and managing director of Hummer Winblad Venture Partners, shares her war stories -including her earliest entrepreneurial experiences sewing and selling Barbie doll clothes; how she convinced a bank to lend her money for her first company; and what she learned from other entrepreneurs, family members and ABBA. She also discusses the qualities that make entrepreneurs successful: having a mission as well as a product, and giving your all to your company, colleagues, industry and the causes you're passionate about.

\section{Read More:}

Advice, Best Practices and Inspiration for Women Entrepreneurs(https://eiexchange.com/women)

Additional search terms: women, feminism, female founders, women business owners, women success stories, women in business, glass ceiling, sexual discrimination, bias, opportunity, finding investors, how do I find money for my business, how do I find investors 